\title{
Importance of Psychiatric Evaluation and Patient Selection in the Field of Cosmetic Dermatology
}

\author{
Stephen M Matlock ${ }^{1 *}$ and Blake Richardson $\mathbf{M}^{2}$ \\ ${ }^{1}$ Department of Dermatology, College of Medicine University of Arkansas for Medical Sciences, USA \\ ${ }^{2}$ College of Medicine University of Arkansas for Medical Sciences, USA
}

Submission: January 27, 2020; Published: February 04, 2020

*Corresponding author: Stephen Matlock, Department of Dermatology, College of Medicine University of Arkansas for Medical Sciences, USA

Keywords: Psychiatric Evaluation; Cosmetic; Dermatology; Body Dysmorphic Disorder

\section{Introduction}

Cosmetics is an ever-increasing component of every-day practice for dermatologists. However, as elective procedures such as neuromodulator injections, dermal fillers, and body contouring have pushed their way into most dermatology practices, little objective research has been done to identify ideal patients to undergo these procedures. It is the opinion of these authors that objective studies to evaluate the pre and post procedural psychologic well-being are essential to identify patients who may have an underlying and undisclosed psychiatric illness that is contributing to their decision-making process. This issue is further complicated by the plethora of cosmetic day-spas that offer these services without physician oversite or ethical obligation to responsibly select candidates. One example regarding the importance of patient selection is exemplified by patients with body-dysmorphic disorder (BDD) - a condition in which the subject has a fixation with one or more perceived flaws in their appearance.

Some studies have reported as high as $12 \%$ of patients seen in a dermatology clinic are afflicted with this disorder, and it is our opinion that part of the solution in managing patients such as this is through proper identification and preventing unnecessary procedures that may serve to reinforce their delusion [1]. Furthermore, the rapid growth of sensitive cosmetic procedures such as non-surgical penoplasy is a relatively new field in which previously developed procedures are being creatively applied in ways that are wholly unstudied with regards to the appropriate patient populations. We feel that in order to responsibly select patients, a simple screening tool used for pre and post procedure evaluation of their happiness and/or psychologic well-being would serve as a simple way for clinicians to help monitor their patient's satisfaction while preventing procedures on patients who may never be satisfied. There are very few studies which use such tools, most of which only assess post-procedure scores. Of the limited studies available, some scoring systems that have been used include the Happiness Measures Scale, FACE-Q, and Derriford Appearance Scale (Litner). [2-4] Of course, without any reports of studies that evaluate the patient's perception of their problem both before and after a cosmetic procedure, clinicians will not have a baseline in which to compare their patient's results.

\section{Conclusion}

In summary, the field of cosmetic dermatology is growing rapidly and can be expected to continue this trend for years to come. It is the responsibility of the physician to understand what is driving their patient's decisions and interpret if there is a psychiatric illness contributing. In order to do this, we feel there must be an objective means to measure dissatisfaction and satisfaction before and after any cosmetic procedure is pursued with emphasis on pre-procedure evaluation.

\section{References}

1. Koblenzer CS (2017) Body dysmorphic disorder in the dermatology patient. Clin Dermatol 35(3): 298-301.

2. Dayan SH, Bacos, JT, Gandhi, ND, Ho TVT, Kalbag A (2019) Assessment of the impact of perioral rejuvenation with hyaluronic acid filler on projected first impressions and mood perceptions. Dermatol Surg 45(1): 99-107. 
3. Mori S, Lee EH (2019) Beyond the physician's perspective: a review of patient-reported outcomes in dermatologic surgery and cosmetic dermatology. Int J Womens Dermatol 5(1): 21-26.
4. Litner JA, Rotenberg BW, Dennis M, Adamson PA (2008) Impact of cosmetic facial surgery on satisfaction with appearance and quality of life. Arch Facial Plast Surg 10(2): 79-83.ss

\section{Your next submission with Juniper Publishers will reach you the below assets}

- Quality Editorial service

- Swift Peer Review

- Reprints availability

- E-prints Service

- Manuscript Podcast for convenient understanding

- Global attainment for your research

- Manuscript accessibility in different formats (Pdf, E-pub, Full Text, Audio)

- Unceasing customer service

Track the below URL for one-step submission https://juniperpublishers.com/online-submission.php 